\title{
Freedom of Speech as a Cultural Holdover
}

\author{
R. George Wright
}

\section{TABLE OF CONTENTS}

I. Introduction. 235

II. The Court Recognizes, and Then Gradually Loses Clarity with Respect to, Foundational Free Speech Values

III. The Traditional Free Speech Values and the Gradual Flattening of Their Meaning

IV. The Worth of Freedom of Speech as Dependent Upon Its Broader Cultural Context....

V. Some Competing Value Costs of Free Speech Under Contemporary Cultural Conditions

VI. Conclusion 270

\section{Introduction}

The constitutionally protected status of speech is a familiar feature of our jurisprudence. ${ }^{1}$ Free speech claims are often upheld at the cost of significant competing public and private interests. It is certainly possible to critique free speech case law for unjustly adjudicating these conflicts merely in one or more special contexts. ${ }^{2}$ The focus of this Article, however, is broader.

* Lawrence A. Jegen Professor of Law, Indiana University Robert H. McKinney School of Law.

1. See, e.g., Floyd Abrams, The Soul of the First Amendment (2017) (providing a broad defense of much contemporary free speech law by one of its leading architects). As the focus of this Article is on state action in First and Fourteenth Amendment free speech jurisprudence, we largely set aside concerns over private corporate actor restrictions on, e.g., useful access to internet search engines and social media sites.

2. See Steven H. Shiffrin, What's Wrong With the First Amendment? (2016) (urging revisions in both directions of the coverage and stringency of free speech protection according to context). See, e.g., THE PRICE WE PAY: THE Case Against Racist Speech, Hate Propaganda, and Pornography (Laura Lederer \& Richard Delgado eds., 1995); Brian Leiter, The Case Against Free Speech, 38 SYDNEY L. REV. 407 (2016) ("TT]he central question in free speech jurisprudence should really be how to regulate speech effectively-to minimize its very real harms, without undue cost to is positive values."); Anthony Leaker, Against "Free Speech", CATo UnBound (June 13, 2018), www.cato- 
This Article proposes that the constitutional status of freedom of speech depends on the current existence of some sufficient sustaining foundations in cultural beliefs and values. Our culture, however, has evolved in such a way as to now make the general constitutionally protected status of speech into, at best, an anachronism. Constitutionalized freedom of speech is, at this point, a holdover from a time ${ }^{3}$ in which supportive cultural beliefs and values sufficiently underwrote our protective free speech jurisprudence. ${ }^{4}$ The traditional grounds upon which freedom of speech was constitutionally prioritized

unbound.org/2018/06/13/anthony-leaker/against-free-speech ("[F]ree speech has been co-opted to serve anti-democratic ends; [it] has become the rallying point of decidedly unemancipatory political formations, invoked to attack equal rights, social justice, and basic norms of tolerance and inclusion . . ..").

3. This formulation implies that there was some prior time in which cultural beliefs and values, and their institutional embodiment, better supported the protected constitutional status of speech. Or, more metaphorically, that there was a time in which the cultural soil was more conducive to the healthy rootedness of freedom of speech. It is certainly possible to argue, though, that there was never a time in which freedom of speech was well sustained by the underlying culture. In this Article, we focus on the plausible claim that cultures can evolve over time in ways more, or less, supportive of the constitutionally protected status of speech. This approach does not deny that some elements of our culture that tend to either sustain or undermine the status of free speech have remained constant and unchanging. Nor does this approach claim that cultural support for the constitutional status of free speech has more or less collapsed, as opposed to diminishing to a significant degree.

4. It is, however, debatable whether there has been a "steady deterioration over the last half century of the essential democratic norm of freedom of speech." Peter Berkowitz, Defending Democratic Norms Requires Defending Free Speech, REAL CleAR POLITICS (Apr. 07, 2019), https://www.realclearpolitics.com/articles/2019/04/07/defending_democratic_n orms_requires_defending_free_speech_139981.html. See, e.g., James L. Gibson, Intolerance and Political Repression in the United States: A Half Century After McCarthyism, 52 AM. J. PoL. SCI. 96 (Jan. 2008). See also Richard D. Schwartz, Stouffer: Communism, Conformity, and Civil Liberties: A Cross-Section of the Nation Speaks Its Mind, 65 YALE L. J. 572 (1956) (demonstrating substantial popular opposition to meaningful freedom of speech. Also reporting majority or near majority opposition to the speech rights of, e.g., admitted communists, atheists, and socialists); Jeremy BauerWolf, Survey: Tepid Support for Free Speech Among Students, Inside HigheR ED (Jan. 30, 2019), https://www.insidehighered.com/quicktakes/2019/01/30/survey-tepid-supportfree-speech-among-students (summarizing Speaking Freely: What Students Think About Expression at American Colleges, FoUNDATION FOR INDIVIDUAL RIGHTS IN EDUCATION (2018), https:/d28htnjz2elwuj.cloudfront.net/wpcontent/uploads/2019/03/05104349/Student-Attitudes-AssociationSurvey.pdf). 
have been gradually dissipating, and no sufficient alternative justifying grounds have taken their place. ${ }^{5}$

The standard justifications for constitutionalizing free speech have eroded and become less meaningful. The elevated constitutional status of freedom of speech can no longer be justified by pointing to any sufficient cultural grounding for that status. Cultures change over time ${ }^{6}$ in ways relevant to the status of freedom of speech. In our cultural context, for example, it is possible that massive aggregate wealth, however maldistributed or unstable, has depleted the cultural values and beliefs needed to justify constitutional freedom of speech. ${ }^{7}$ Collective wealth and other cultural factors can seem to insulate us from the consequences of various forms of public speech that

5. Of course, this is a daunting task in some respects. Our culture has, at all times, manifested speech taboos; shibboleths; public and private speech suppression of various sorts; numbing campaigns of meme-repetition; agendaskewing; indignant shaming; mobbing; intimidation; exclusionism; egodefensive pathologies; and propagandized understandings of free speech itself. Some account must also be taken of the effects on our public discourse of the current technology-driven broadening of who can speak in some publicly accessible fashion. Even if the number of U.S. monthly users of Twitter in particular has recently declined, there are currently at least 60 million such users. See J. Clement, Twitter: Number of Monthly Active U.S. Users 2010 2019, STATISTA (Aug. 9, 2019), https:/www.statista.com/statistics/274564/monthly-active-twitter-users-inthe-united-states/.

6. Under one conventional approach, a hypothetical culture may, over time, exhibit various mixtures of initial barbarism, mature civilization, decadence and exhaustion, and ultimately a combination of self-indulgence and a drive toward self-extinction. Like the mythic Sibyl at Cumae, some civilizations may, in a sense, wish to die. See H.D. Cameron, The Sibyl in the Satyricon, 65 Classical J. 337 (1970). See, e.g., JACques Barzun, From DaWn to Decadence: 1500 to the Present: 500 Years of Western Cultural Life (1st ed. 2001); DAVID WEIR, DECADENCE: A VERY SHORT INTRODUCTION (2018). See also G.W.F. Hegel, Author's Preface, Philosophy of Right (T.M. Knox trans. 1952, 1969 ed.) (1821) (suggesting that only with civilizational decline does wisdom arrive. Hegel did not, however, guarantee that all declining civilizations will have the resources necessary to recognize the causes of their decline). See generally EDWARD CAIRD, HEGEL (1972) (discussing Hegel's understanding of cultural vitality and development in his letter to Zeilmann in which Hegel views the French Revolution as leaving behind the "baby shoes" and "fetters" of the Ancient Regime).

7. See, e.g., Daniel Bell, The Cultural Contradictions of Capitalism: 20TH ANNIVERSARY EDITION (1996) (discussing themes from MANCUR OLSON, The Rise and Decline of Nations: Economic Growth, Stagflation, And SOCIAL Rigidities (1982) and JOSEPH A. SCHUMPETER, CAPITALISM, SOCIALiSM AND DEMOCRACY (3d ed. 2008)). 
increasingly reflect one sort of pathology or another. ${ }^{8}$

Our focus is not upon economics as it affects culture but on several important aspects of culture insofar as they affect the net value of speech. In particular, we consider first the official legal cultural beliefs embodied in Supreme Court opinions, as those beliefs have evolved over time. ${ }^{9}$ The Court's free speech jurisprudence itself has already lost any clear, coherent, and consistent sense of what the free speech clause is to mean and to accomplish. ${ }^{10}$

Given the evolving case law, we then consider the commonly accepted basic values thought to underlie the constitutionally privileged status of speech. ${ }^{11}$ The Article then points out the consequences, over time, of the underlying culture's thinning out and minimalizing what these underlying values amount to. ${ }^{12}$ This "thinning out" of our sense of what the free speech values really amount to crucially impeaches the logic of according specially protected constitutional status to speech at the expense of other values and interests. ${ }^{13}$

These crucial effects of the changes in our cultural understanding of the status and meaning of the values underlying freedom of speech are, in turn, enhanced by a range of important recent cultural trends in education and other spheres. ${ }^{14}$ The benefits of freedom of speech have been gradually reduced because of these sustained cultural trends. We then illustrate, through the case law, some important increasing cultural costs incurred when current free speech claims override significant conflicting values. ${ }^{15}$ A brief Conclusion then follows. ${ }^{16}$

8. See generally AnNa Freud, The EgO AND the MECHANISMS OF DEFENCE (Routledge ed. 1992) (discussing, inter alia, what has become increasingly prominent public speech phenomena of denial, projection, and displacement of affect).

9. See infra Part II.

10. See infra Part II.

11. See infra Parts II, III.

12. See infra Parts II, III.

13. See infra Parts II, III.

14. See infra Part IV.

15. See infra Part V.

16. See infra Part VI. 
II. The Court Recognizes, and Then Gradually Loses Clarity with Respect to, Foundational Free Speech Values

The history of the Supreme Court's free speech jurisprudence is complex and not susceptible to simple generalization. Clearly, though, there are historic moments of judicial endorsement of basic speech values that resonate and, in a sense, persist. ${ }^{17}$ But those moments may lose their importance over time, particularly when the broad underlying culture no longer genuinely validates the basic free speech values in question.

Among these classic moments of the judicial endorsement of underlying free speech values would be judicial assertions that the First Amendment should favor "free trade in ideas," 18 and that "the best test of truth is the power of the thought to get itself accepted in the competition of the market...."19 More elaborately, Justice Brandeis celebrated the values of "the discovery and spread of political truth," 20 deliberation rather than arbitrariness of government, ${ }^{21}$ and the development of one's faculties, ${ }^{22}$ all through freedom of speech. ${ }^{23}$

These themes were then pursued in later cases, such as Thornhill v. Alabama ${ }^{24}$ and Keyishian v. Board of Regents. ${ }^{25}$ And it is fair to say that themes-such as the pursuit of truth, promoting democratic self-government, and facilitating selfrealization, as presumably promoted by constitutional freedom

17. See, e.g., Thomas IrWin EMERson, The System of FreEdom of Expression (1970); Harry Kalven, Jr., A Worthy Tradition: FreEdom of SPEECH IN AMERICAN (Jamie Kalven ed., 1988).

18. Abrams v. United States, 250 U.S. 616, 624, 630 (1919) (Holmes, J., dissenting).

19. Id. See also Nat'l Inst. Family \& Life Advocates v. Becerra, 138 S. Ct. 2361,2375 (2018)

20. Whitney v. California, 274 U.S. 357, 375 (1927) (Brandeis, J., concurring).

21. Id.

22. $I d$.

23. $I d$.

24. 310 U.S. 88, 95 (1940) (discussing "the power of free and fearless reasoning and communication of ideas to discover and spread political and economic truth" as well as the role of freedom of speech in "popular government").

25. 385 U.S. 589, 603 (1967) (discussing classrooms as "peculiarly the "marketplace of ideas" through which "the robust exchange of ideas" may lead to the discovery of truth without any censorial skewing or pre-selection). 
of speech-continue to arise in the Court's ongoing free speech jurisprudence. But it is also fair to say that in recent years, the Court's concern for these purported basic free speech values has been gradually diminishing. This latter development reflects, with some time lag, broad cultural shifts in the meaning, depth, and significance of the classic free speech values and their obvious assumptions and prerequisites.

The Court's gradually diminishing reliance on the classic free speech values does not imply that the Court has contracted the scope of free speech protection; typically, far from it. In particular, the Court has come to adopt the speech of pure commercial transactions between sellers and buyers of consumer goods and services as falling within the scope and protection of the free speech clause. ${ }^{26}$ Purely commercial barroom nude dancing, undertaken for the sake of increased income, is also now assumed to be within the compass of freedom of speech. ${ }^{27}$ So is speech in the form of a deliberate lie, uttered merely for the sake of deceiving an audience into according undeserved respect to the speaker, to the effect that the speaker has been awarded the Congressional Medal of Honor. ${ }^{28}$ Scrupulous concern for the free speech rights of traffickers in the video depiction of the torturous extinction of helpless animals is judicially observed. ${ }^{29}$ Restrictions on the sale to minors of especially violent video games, even when the game is held to lack serious relevant value, ${ }^{30}$ violate freedom of speech, ${ }^{31}$ partly on the grounds of the murkiness of any line between politics and sheer entertainment. ${ }^{2}$ Speech, whether protected or not, has been detected even in the professed absence of any intent to convey any relevant message. ${ }^{33}$

26. See generally Va. State Bd. of Pharmacy v. Va. Citizens Consumer Council, 425 U.S. 748, 765 (1976) (discussing pure commercial product advertising).

27. See, e.g., Barnes v. Glen Theatre, Inc., 501 U.S. 560, 563, 565-66 (1991) (Rehnquist, C.J., plurality).

28. See United States v. Alvarez, 567 U.S. 709, 727-28 (2012) (Kennedy, J., plurality).

29. See United States v. Stevens, 559 U.S. 464, 465-66 (2010).

30. See Brown v. Entm't Merchs. Ass'n, 564 U.S. 786, 789 (2011).

31. Id. at 791-93.

32. Id. at 790 (" $[\mathrm{I}] \mathrm{t}$ is difficult to distinguish politics from entertainment and dangerous to try.").

33. See, e.g., Morse v. Frederick, 551 U.S. 393, 401 (2007) (discussing a banner that stated "Bong Hits For Jesus" as, per Frederick himself, "just 
The point is not that any of these cases was rightly or wrongly decided, or that the current Court always decides free speech cases in the spirit of these cases. Rather, the idea is that these cases, whether mistaken or not, generally do not rely on the logic of any of the Court's classic expositions of the basic values thought to underlie the specially protected status of speech. Thus, while each of the cases above may be defensible, it would be difficult to persuasively defend these cases by appeal to the values endorsed historically in the Abrams dissenting opinion, ${ }^{34}$ the Whitney concurring opinion, ${ }^{35}$ the Thornhill opinion, ${ }^{36}$ the Keyishian opinion, ${ }^{37}$ or any other such classic basic free speech value statement.

This is not to suggest that the Court has begun to consciously reduce its reliance on the classic free speech values or on any metaphysically ambitious understanding of those values. There are indeed instances of a reduced judicial focus on truth, democracy, and self-realization as underlying guides in free speech cases. As the Court's thinking comes to be influenced by the evolving cultural life and the elite and popular metaphysical assumptions of the day, the Court's assumptions need not be explicitly articulated by the Court.

Courts generally need not even be aware of, let alone articulate, the evolving cultural assumptions underlying their opinions. Lord Keynes famously observed a cultural process of elite influence and its generally unrecognized character in declaring that even " $[\mathrm{m}]$ admen in authority ... are distilling their frenzy from some academic scribbler of a few years back. I am sure that the power of vested interests is vastly exaggerated

nonsense meant to attract television cameras"). See also Barnes v. Glen Theatre, Inc., 501 U.S. 560, 563, (1991) (Rehnquist, C.J., plurality); Burge v. Colton Sch. Dist. 53, 100 F. Supp. 3d 1057, 1060 (D. Or. 2015) (holding that protected, on free speech grounds, a student's social media post to the effect that a low grade-assigning teacher "needs to be shot"). In the broader context, it is apparently well-established that freedom of speech protects rude gestures directed toward a particular police officer. See Cruise-Gulyas v. Minard, 918 F.3d 494, 497 (6th Cir. 2019) (citing Sandul v. Larion, 119 F.3d 1250, 1255 (6th Cir. 1997)).

34. See Abrams v. United States, 250 U.S. 616, 624-31 (1919) (Holmes, J., dissenting).

35. See Whitney v. California, 274 U.S. 357, 372-80 (1927) (Brandeis, J., concurring).

36. See Thornhill v. Alabama, 310 U.S. 88 (1940).

37. See Keyishian v. Board of Regents, 385 U.S. 589 (1967). 
compared with the gradual encroachment of ideas." 38 Similar largely elite-level influences, whether direct or indirect, undiluted or diluted, articulated or in-articulated, would affect Supreme Court members as well. ${ }^{39}$

As we might expect, the Court displays ambivalence as to the nature of any grounds underlying the constitutional commitment to freedom of speech. Consider, for example, the striking, if largely unacknowledged, contrast in approach between the direct political protest case of Cohen $v$. California ${ }^{40}$ and the "seven dirty words" case of FCC $v$. Pacifica Foundation. ${ }^{41}$ The two case outcomes may be compatible, but they clearly bespeak two distinct understandings of how culture informs free speech laws.

The Cohen case thus invokes the classic Brandeis concurrence in Whitney, ${ }^{42}$ but then famously declares that

While the particular four letter word being litigated here is perhaps more distasteful than most others of its genre, it is nevertheless often true that once man's vulgarity is another's lyric. Indeed, we think it is largely because government officials cannot make principled distinctions in this area that the Constitution leaves matters of taste and style so largely to the individual. ${ }^{43}$

Courts generally do not attempt to do philosophy. So we should not expect the Court to announce its endorsement, in this respect, of any sort of underlying relativism, subjectivism, or of

38. JoHn MAYNARD Keynes, The General TheOry of Employment, INTEREST, AND MONEY 383 (2018 ed.) (1938).

39. See generally LAWREnCE BAUM, JUdGES AND THEIR AUdiEnCES: A Perspective on Judicial Behavior (2006); Neal Devins \& LaWrence Baum, The Company They Keep: How Partisan Divisions Came to the Supreme COURT (2019) (discussing elite and other cultural influences on the Supreme Court with an emphasis on partisan political conflict).

40. 403 U.S. 15 (1971).

41. 438 U.S. 726 (1978) (plurality opinion).

42. See Cohen, 403 U.S. at 25 (citing Whitney v. California, 274 U.S. 357 , 375-77 (1927) (Brandeis, J., concurring)).

43. Id. See also Brief for the Cato Inst, et al, as Amici Curiae Supporting Respondent, Iancu v. Brunetti, 139 S.Ct. 2294 (2019) (No. 18-302), 2018 WL 7890204 ("[T]here cannot be one consensus standard of 'scandalous language' in a heterogeneous society."). 
underlying arbitrariness. In referring to the question as merely one of "taste and style," 44 the Court clearly draws upon these rationally modest categories. Of taste, after all, there is proverbially no disputing. ${ }^{45}$ A genuine preference for the taste of vanilla over strawberry is hardly subject to evidence-based debate. Such preferences require neither interesting metaphysical assumptions nor controversial foundations.

Crucially, the Court in Cohen then apparently links the use of profanity with valuable emotional fervor, and reports that

Much linguistic expression serves a dual communicative function .... [W]ords are often chosen as much for their emotive ${ }^{46}$ as for their cognitive force. We cannot sanction the view that the Constitution ... has little or no regard for that emotive function which, practically speaking, may often be the more important element of the overall message sought to be communicated. ${ }^{47}$

Whatever the contribution of emotion itself to the logic of constitutionally protecting speech may be, ${ }^{48}$ emotional expression by itself typically does not make any crucial assertions that can be meaningfully investigated as to their

44. Cohen, 403 U.S. at 25.

45. See De gustibus non est disputandum, MERRIAM WEBSTER, https://www.merriam-

webster.com/dictionary/de $\% 20$ gustibus $\% 20$ non $\% 20$ est $\% 20$ disputandum (last visited Oct. 26, 2019) ("[T]here is no disputing about taste"). See also DAVID Sobel, From Valuing to Value: A Defense OF SubJectivism (1st ed. 2016) (providing a sophisticated approach to the subjectivity of values).

46. Authors have elaborated on the subject at a more formal meta-ethical level. See, e.g., Alfred Jules Ayer, Language, Truth \& Logic (2d ed. 1952); Charles L. Stevenson, Ethics and Language (1944); J.O. Urmson, Emotive THEORY OF ETHICS (1968); Stephen A. Satris, The Theory of Value and the Rise of Ethical Emotivism, 43 J. HIST. IDEAS 109 (1982). See also Richard Joyce, Moral Anti-Realism, STAN. Encyclopedia PHIL. (Feb. 11, 2015), https:/plato.stanford.edu/entries/moral-anti-realism; Mark von Roojen, Moral Cognitivism vs. Non-Cognitivism, Stan. EnCyClopedia PHIL. (June 28, 2018), https://plato.stanford.edu/entries/moral-cognitivism.

47. Cohen, 403 U.S. at 26.

48. See generally R. George Wright, An Emotion-Based Approach to Freedom of Speech, 34 LOY. U. CHI. L. REV. 429 (2003) (discussing Cohen v. California, 403 U.S. 15 (1971)). 
truth or falsity in any objective or grounded sense. ${ }^{49}$ Emotions themselves are doubtless often based on beliefs that may be true or false. But the emotional expression by itself does not state some proposition claiming any objective grounding in the world, beyond the speaker's own subjectivity.

By contrast, in FCC v. Pacifica Foundation, ${ }^{50}$ the Court plurality adopted a significantly different approach than in Cohen. One might imagine that George Carlin's "seven dirty words," as expressed in his recorded monologue in Pacifica, ${ }^{51}$ could reasonably be thought of as vulgar, offensive, shocking, or not, depending upon one's tastes and political sensibilities. That would reflect the Court's approach to Cohen. However, the Court plurality in Pacifica instead peremptorily declares that "it is undisputed that the content of Pacifica's ["seven dirty words"] broadcast was 'vulgar,' 'offensive,' and 'shocking." 52

The undisputed vulgarity, offensiveness, and shockingness of George Carlin's monologue might have come as a surprise to some of its willing listeners, if not to the defendants. What should have been undisputed, under the Cohen precedent, was that some people, certainly, would find the monologue vulgar, offensive, and shocking. Restricting speech that predictably offends some people but not others is a possible rule, but not a rule that Pacifica endorses.

Pacifica, however, leaves unclear the real basis for declaring that the Carlin language is vulgar, offensive, and shocking. Perhaps the underlying logic is that the Carlin monologue really is - or else really and objectively should be judged-vulgar, offensive, and shocking by any reasonable person. This interpretation would emphasize any possible objective grounds underlying such a judgment. Or perhaps the Court instead recognized the sheer disputability and relativism of any such judgment, and then, consistent with that relativism, chose merely to endorse and impose its own subjectively preferred

49. One might consider an honest and sincere emotional expression to be, perhaps, overwrought, or otherwise inappropriate, but the Court in Cohen is explicitly separating emotive speech, or its supposed equivalent, emotional speech, from speech with cognitive content.

50. Compare FCC v. Pacifica, 438 U.S. 726 (1978) (plurality opinion), with Cohen v. California, 403 U.S. 14 (1971).

51. See Pacifica, 438 U.S. at $745-47$.

52. Id. at 747 . 
view. 53

More decisively, though, it is clear that Pacifica affords less scope for the constitutional protection of emotive speech than was contemplated in Cohen.54 For the Cohen Court, the cognitive and emotive meanings of an expression may be inseparable, or of comparable importance, for free speech purposes. ${ }^{55}$ In contrast, the Pacifica plurality contends for the general separability of the message's content from the way, perhaps emotional, in which that content is delivered. Thus the Pacifica Court declared that "[a] requirement that indecent language be avoided will have its primary effect on the form, rather than the content, of serious communication. There are few, if any, thoughts that cannot be expressed by the use of less offensive language." 56

Overall, we have herein no interest in endorsing any particular approach to typical free speech cases. Rather, our point is to highlight the increasingly uncertain relationship between the Court's free speech jurisprudence and the basic values commonly thought to underlie that jurisprudence. The meaning, import, substance, and implications of those underlying values seem increasingly unclear. Immediately below, we briefly focus on the basic historic underlying free speech values themselves and begin the process of accounting for the Court's increasing lack of clarity and certainty in these respects.

\section{The Traditional Free Speech Values and the Gradual Flattening of Their Meaning}

There has long been a reasonably broad consensus as to the most important values thought to justify according special

53. Any logical relationship between relativism and tolerance is dubious at best. One's group perspective may simply endorse imposing the group's substantive perspective on other groups, with no pretense to objective rightness or wrongness of any stance. See Maria Baghramian \& J. Adam Carter, Relativism, STAN. ENCYClopedia PHIL. (Sept. 11, 2015), https:/plato.stanford.edu/entries/relativism; Chris Gowans, Moral Relativism, STAN. ENCYCLOPEDIA PHIL (Apr. 20, 2015), https:/plato.stanford.edu/entries/moral-relativism/.

54. See sources cited supra notes 40-43.

55. See Wright, supra note 48.

56. Pacifica, 438 U.S. at 743 n.18. 
constitutional protection to much speech. While the basic free speech values list can be expanded, ${ }^{57}$ there is much agreement as to the roles of: (1) promoting in particular a general search for truth; (2) facilitating a meaningful process of democratic government; and (3) encouraging meaningful self-realization, self-actualization, or genuine autonomy.

Probably the most striking defense of these three underlying values on the merits has been John Stuart Mill's classic On Liberty. ${ }^{58}$ In particular, Mill's exposition of the values of truth and, especially, of meaningful self-realization conveys the sense that some states of affairs are, whether we all agree or not, objectively higher or better than others. ${ }^{59}$

The three basic free speech values have of late been explicitly identified by a number of American constitutional law writers, including: Thomas Emerson ${ }^{60}$; Frederick Schauer ${ }^{61}$; Mark Tushnet, Alan K. Chen, and Joseph Blocher ${ }^{62}$; Kent Greenawalt ${ }^{63}$; and Alexander Tsesis. ${ }^{64}$ And the values of the

57. See generally LeE C. Bollinger, The TOLERAnt Society (2d ed. 1988) (discussing the distinctive emphasis on tolerance); Vincent Blasi, The Checking Value in First Amendment Jurisprudence, 2 AM. B. FOUND. RES. J. 521 (1977) (discussing the government-checking function of speech).

58. See John Stuart Mill, ON Liberty 115-28 (Gertrude Himmelfarb ed., Penguin Group 1974) (1859)

59. Id. at 127-28 (discussing higher, better, and more fully developed characters). See also John STUART MiLl, UTILITARIANism 10 (George Sher ed., $2 d$ ed. 1863) ("It is better to be ... Socrates dissatisfied than a fool satisfied. And if the fool... [is] of a different opinion, it is because they only know their own side of the question.").

60. See generally Thomas I. Emerson, The System of Freedom of EXPRESSION 6-7 (1970) (referring to "assuring individual self-fulfillment," "advancing knowledge and discovering truth," universal "participation in decision making," along with balancing "healthy cleavage and necessary consensus," or a "balance between stability and change").

61. See generally Frederick Schauer, Free Speech: A Philosophical ENQUTRY (1982) (discussing arguments from pursuing truth, from promoting popular sovereignty, and from self-development through social communication).

62. See generally Mark V. Tushnet, ALAn K. Chen, \& Joseph Blocher, Free SPEech Beyond Words: THE SURPRising REACH OF THE First AMENDMENT (2017).

63. See generally Kent Greenawalt, Free Speech Justifications, 89 CoLum. L. REv. 119, 130-47 (1989) (discussing, among other values, "truth discovery," "autonomy and personal development," and "the functioning of liberal democracy").

64. See generally Alexander Tsesis, Free Speech Constitutionalism, 2015 U. ILL. L. REV. 1015, 1016 (2015) (identifying the desire "to further democratic 
pursuit of truth, ${ }^{65}$ meaningful democratic governance, ${ }^{66}$ and selfrealization and autonomy ${ }^{67}$ have been the subject of continuing

institutions," to promote "personal autonomy," and "the advancement of knowledge," while arguing for the excessive narrowness and incompleteness of this value enumeration).

65. See, e.g., C. Edwin Baker, Scope of the First Amendment Freedom of Speech, 25 UCLA L. REV. 964, 965 (1978) (denying the existence of objective truth); Christopher Bezemek, The Epistemic Neutrality of the Marketplace of Ideas: Milton, Mill, Brandeis, and Holmes on Falsehood and Freedom of Speech, 14 FiRst AMEND. L. REV. 159 (2015); Stanley Ingber, The Marketplace of Ideas: A Legitimizing Myth, 1984 DUKE L. J. 1, 5 (1984) (noting the waning popularity of the idea of objective truth); William P. Marshall, In Defense of the Search for Truth as a First Amendment Justification, 30 GA. L. REV. 4, 25 (1995) (stating "objective truth may (or may not) be non-existent or unintelligible," but the "truth" value to be realized is not in the possible attainment of truth, but rather, in the "existential [and thus actually or potentially non-objective] value of the search itself") (stating "reliance on the actual existence of truth is not necessary to support the search for truth rationale"); Frederick Schauer, Free Speech, the Search for Truth, and the Problem of Collective Knowledge, 70 SMU L. REV. 231 (2017); Frederick Schauer, Reflections On the Value of Truth, 41 CASE W. RES. L. REV. 699, 724 (1991) ("T]he issue is often power rather than truth, and . . the value of truth (or knowledge) often lies in its being instrumental to some deeper value such as (but not limited to) power"); Steven D. Smith, Skepticism, Tolerance, and Truth in the Theory of Free Expression, 60 S. CAL. L. REV. 649 (1987); Irene M. Ten Cate, Speech, Truth, and Freedom: An Examination of John Stuart Mill's and Justice Oliver Wendell Holmes's Free Speech Defenses, 22 YALE J. L. \& Human. 35 (2013); Christopher C. Wonnell, Truth and the Marketplace of Ideas, 19 U. C. DAVIS L. REV. 669, 672 (1986). Beyond the legal literature, consider the traditionalist belief in a "desire to know" that is "independent of the individual's likes and dislikes, or his wishful and anxious thinking." BERNARD LONERGAN, INSIGHT: A STUDY OF HUMAN UNDERSTANDING, in COLLECTED Works OF BERNARD LONERGAN 619 (Frederick E. Crowe \& Robert M. Doran eds., 5th ed. 1992).

66. See, e.g., Jack M. Balkin, Cultural Democracy and the First Amendment, 110 Nw. U. L. REV. 1053, 1054 (2016) ("Freedom of speech does more than promote democracy; it also promotes a democratic culture" (emphasis in original)); Jack M. Balkin, Digital Speech and Democratic Culture: A Theory of Freedom of Expression For the Information Society, 79 N.Y.U. L. REV. 1, 3 (2004) (emphasizing the possibilities for both new opportunities for cultural participation and new mechanisms for constricting and skewing such participation); Ashutosh Bhagwat, The Democratic First Amendment, 110 NW. U. L. REV. 1097 (2016) (emphasizing Jeffersonian meaningful and active citizenship); Blasi, supra note 57; Robert Post, Participatory Democracy and Free Speech, 97 VA. L. REv. 477, 482 (2011) ("[T]he best possible explanation of the shape of First Amendment doctrine is the value of democratic self-governance."). Professor Post also endorses the consensus on the three core free speech values. See id. at 478. See also Kate Klonick, The New Governors: The People, Rules, and Processes Governing Online Speech, 131 HaRV. L. REV. 1598 (2018).

67. See, e.g., Floyd ABrams, The Soul of the First Amendment 22 (2017) 
debate.

For our purposes, we assume that some combination of one or more of these traditionally cited values can-at least on some possible definitions and under some possible cultural circumstances-suffice to justify special constitutional protection for speech. The problem, though, is that under our continually evolving cultural circumstances, the meaning and, crucially, the depth of meaning of the key concepts has significantly changed. These changes in meaning, in general, have been in the direction of the thinning out, flattening, reduction in depth, reduction in ambition, insubstantiality, and even the moral trivialization of the terms in question.

Thus the very idea of truth, most crucially, today tends not to mean what it once might have meant. Similarly, the ideas of self-realization, of the development of one's potential, and of autonomy have tended to flatten, undergo minimization, and to be reduced to more superficial understandings than might once have been the case. Even our understandings of democratic self-

(emphasizing Thomas Emerson's concern for "individual self-fulfillment" through freedom of speech); CASS R. SUNSTEIN, ON FREEDOM (2019) (emphasizing agency and autonomy with no distinctive reference to freedom of speech in particular); C. Edwin Baker, Autonomy and Free Speech, 27 ConsT. COMMENT. 251, 253 (2011) (discussing autonomy as "the capacity to pursue successfully the life she endorses-self-authorized at least in the sense that, no matter how her image of a meaningful life originates, she now can endorse that life for reasons that she now accepts"); Id. at 966 (focusing on speech that "fosters individual self-realization and self-determination"); Susan J. Brison, The Autonomy Defense of Free Speech, 108 ETHCS 313 (1998) (discerning and critiquing six distinguishable senses of the idea of autonomy); Richard $\mathrm{H}$. Fallon, Jr., Two Senses of Autonomy, 46 STAN. L. REV. 875, 877-78 (1994) (distinguishing "descriptive" autonomy from "ascriptive" or (largely) normatively recognizable autonomy, or a right thereto); Stephen M. Feldman, Postmodern Free Expression: A Philosophical Rationale for the Digital Age, 100 MARQUETTE L. REV. 1123 (2017) (focusing on autonomy as self-emergence based on "relational" autonomy); Brian C. Murchison, Speech and the SelfRealization Value, 33 HARV. C.R.-C.L. L. REV. 443 (1998); Martin Redish, The Value of Free Speech, 130 U. PA. L. REV. 591, 593 (1982) ("[T]he constitutional guarantee of speech ultimately serves only one true value, which I have labeled 'individual self-realization.'”); T.M. Scanlon, Comment on Baker's Autonomy and Free Speech, 27 CONST. COMMENT. 319, 319 (2011) (stating that, contrary to his own previous beliefs, "the concept of autonomy is not a helpful one"); David A. Strauss, Persuasion, Autonomy, and Freedom of Expression, 91 COLUM. L. REV. 334, 354 (1991) (focusing in particular on autonomy as "a person's control over her own reasoning processes"). For a broader survey, see John Christman, Autonomy in Moral and Political Philosophy, STAN. ENCYCLOPEDIA PHIL. (Jan. 9, 2015), https://plato.stanford.edu/entries/autonomy-moral/. 
governance have undergone a gradual evacuation of depth and substantiality of meaning, due largely to the gradual attention and evacuation of the former meanings of truth and of selfrealization and autonomy.

Crucially, these cultural trends have reached a point at which "truth," "democracy," and "autonomy," as we currently tend to understand them, no longer suffice to appropriately justify a general exaltation of freedom of speech above a wide range of competing public and private desires, preferences, and interests. Our collective culture does not, at this point, ${ }^{68}$ adequately ground a distinctively general constitutionally protected status for speech. ${ }^{69}$ As our understanding of the very ideas $^{70}$ of truth, democracy, and autonomy become increasingly limited, attenuated, and contested, their power to justify inescapably costly constitutional practices and institutions is inevitably reduced.

Most fundamentally, consider the gradual erosion of the depth of meaning and metaphysical ambition of the idea of the pursuit, however fallibly and haltingly, of truth. Where the understanding of truth itself as foundational was perhaps at one point largely taken for granted, or at least familiar, we take ourselves of late to be living in some sort of largely or increasingly "post-truth" culture. "Post-truth" was the Oxford Dictionary's word of the year in $2016 .{ }^{71}$ Of course, this popular usage can itself hardly explain cultural trends before its own rise to prominence. And the idea of post-truth is often used in rather narrow, transient political contexts. ${ }^{72}$

But the idea of a post-truth culture, whatever its precise import, can also draw upon more sustained underlying cultural

68. We leave aside the question of whether our then current understanding of the basic free speech values sufficiently justified constitutionalizing free speech at any point in our cultural history.

69. We also set aside the possibility of adequately justifying constitutionalized free speech by means of some logic apart from reliance on one or more of the consensual basic free speech values discussed later in this article.

70. Thus, our argument does not depend on any claim of increased prevalence of say, lying in public, as long as the dominant cultural understanding of the fundamental nature of lying remains unchanged.

71. Post-truth, OXFORD DICTIONARIES (2016), https://anguages.oup.com/press/news/2016/12/11/WOTY-16.

72. As in its use in describing only particular political actors, as opposed to much broader and sustained cultural phenomena. 
trends, whether at popular or elite cultural levels. ${ }^{73}$ Some analyses of post-truth point to the accruing influence of initially elite-level, but now more broadly influential, post-modernism. ${ }^{74}$ The post-truth culture can be seen, at least in part, as the accruing result of the broadly postmodernist view that the very idea of "a right or wrong answer to what a text (whether written or behavioral) "meant" should be interrogated, though presumably not for its objective truth or falsity. ${ }^{75}$ On this typical understanding of post-modernism, "[s]ince there is no such thing as 'truth,' anyone who claims to 'know' something [or, presumably, even to pursue the truth with humility] is really just trying to oppress us, not educate us. Having power allows us to control what is true, ${ }^{76}$ not the other way around." 77

By implication, if truth is largely reducible to something akin to power, to perspective, to any large number of disparate perspectives, or to indefinitely shifting perspectives not further accountable to anything apart from power, the idea of truth can hardly provide even a contribution to a convincing account of why freedom of speech should, despite its evident costs, be constitutionally enshrined. The basic problem is that as truth's linkage to the idea of any sort of objective reality is loosened or disavowed, ${ }^{78}$ the utility of the idea of truth in justifying broad freedom of speech is thereby reduced or eliminated.

73. See, e.g., Michiko KakuTANi, The DEATh of Truth: Notes on FALSEHOOD IN THE AGE OF TRUMP 73 (2018) ("The postmodernist argument that all truths are partial (and a function of one's perspective) led to a related argument that there are many legitimate ways to understand or represent an event."); $I d$. at 167 (quoting the critic George Saunders to the effect that "[o]ur national language... had become... dumbed down-at once 'aggressive, anxiety-provoking, maudlin, polarizing"'). These phenomena presumably accrue and gain influence over decades.

74. See id.

75. Lee McIntyre, Post-Truth 125 (2018).

76. Cf. Nemo veritatem regit, AM. PHIL. PraCs. Ass'N, https:/appa.edu/ (last visited Oct. 29, 2019) ("Nobody governs truth").

77. MCINTYRE, supra note 75 , at 126.

78. See generally Jennifer KavanaUgh, News in a Digital AgE: Comparing the Presentation of News Information over Time and ACross MEDIA PLATFORMS (2018) (discussing the gradual shift in news reporting over recent decades from aspirations toward objectivity to more subjective, emotional, or advocacy-driven emphases); Rose McDermott, Psychological Underpinnings of Post-Truth in Political Beliefs, 52 POL. SCI. \& POL. 218 (2019); S.I. Strong, Alternative Facts and the Post-Truth Society: Meeting the Challenge, 165 U. PA. L. REV. 137 (2017). 
The effects introduced by a broadly construed postmodernism thus run far deeper than merely new forms of censorship or restrictions on, and difficulties in acquiring and communicating, presumably valuable views and information. ${ }^{79}$ But the relevant cultural trends undermining the basic values thought to underlie freedom of speech are much broader than can be ascribed to post-modernism. As one leading philosopher summarized the matter, "it is fair to say that almost all the trends in the last generation of serious philosophy lent aid and comfort to the 'anything goes' climate ... [and] any hope for a genuine vindication of knowledge and rationality went into retreat." 80

As the widespread references to post-modernism in particular suggest, the effects of various sorts of less ambitious and less robust approaches to the ideas of truth, knowledge, and ethics have gradually extended beyond academic departments. As another leading philosopher observed, "[e]specially within the academy, but also and to some extent outside of it, the idea that there are 'many equally valid ways of knowing the world'... has taken very deep root. In vast stretches of the humanities and social sciences, this sort of 'postmodernist relativism' about knowledge has achieved the status of an orthodoxy."81

Within the scope of philosophy, we find approaches to metaphysics, knowledge, truth, and ethics, a wide range of views that cannot sustainably underwrite any constitutional

79. See generally Allison Orr Larsen, Constitutional Law in an Age of Alternative Facts, 93 N.Y.U. L. REV. 175, 175-77 (2018) (assuming the elusive existence of objective facts, even if as "an endangered species"); Sarah C. Haan, Facebook's Alternative Facts, 105 VA. L. REV. 18, 19-20 (2019) (discussing the fraught relationship between the major social media sites, including Facebook, and the aim of promoting some optimally free mechanism of communicating views and ideas without undue public or private distortion); Sarah C. Haan, The Post-Truth First Amendment, 94 IND. L. J. 1 (2019). More ambitiously, Professor Joseph Blocher seeks to largely bypass the difficulties posed by a post-truth culture by emphasizing not simply truth, or the pursuit thereof, but the idea of knowledge, or distinctly valuable and justified true belief. See Joseph Blocher, Free Speech and Justified True Belief, 132 HARV. L. REV. 3 (2019). Of course, both knowledge and justified true belief, however supplemented, inescapably depend upon some underlying continuing sense of truth.

80. Simon Blackburn, Truth: A Guide 139 (2005)

81. Paul A. Boghossian, Fear of Knowledge: Against Relativism and CONSTRUCTIVISM 2 (2006). 
privileging of free speech. Among these approaches we find, in no particular order: various forms of moral skepticism ${ }^{82}$; moral relativism ${ }^{83}$; moral fictionalism ${ }^{84}$; moral anti- and quasirealism ${ }^{85}$; emotivism ${ }^{86}$; constructivism in ethics ${ }^{87}$ and politics ${ }^{88}$; certain forms of philosophical pragmatism ${ }^{89}$; and various forms of strict materialism ${ }^{90}$ and physicalism.91 Each of these currently popular approaches can be contrasted with varieties of moral realism and with other dimensions of realism and the search for objectivity. ${ }^{92}$

82. See, e.g., Walter Sinnott-Armstrong, Moral Skepticism, STAN. $\begin{array}{llll}\text { ENCYCLOPEDIA PHIL. (May 2019), } & \text { 17, }\end{array}$ https:/plato.stanford.edu/entries/skepticism-moral.

83. See, e.g., Chris Gowans, Moral Relativism, STAn. ENCYClopedia PhIL. (Apr. 20, 2015), https://plato.stanford edu/entries/moral-relativism; Richard Joyce, Moral Objectivity and Moral Relativism, STAN. ENCYCLOPEDIA PHIL. (2016), https://plato.stanford.edu/entries/moral-anti-realism/moralobjectivity-relativism.html.

84. See, e.g., Mard Eli Kalderon, Moral Fictionalism (2005); Richard Joyce, Moral Fictionalism: How to Have Your Cake and Eat It Too, in THE END of Morality: TAKing Moral ABolitionism SERIOUSLy 150 (Richard Garner \& Richard Joyce eds., 2019). See also Matti Eklund, Fictionalism, STAN. ENCYCLOPEDIA PHIL. (Oct. 19, 2015), https:/plato.stanford.edu/entries/fictionalism/.

85. See, e.g., J.L. MACKIE, ETHICs: InVENTING RIGHT AND WRONG (1978); Simon Blackburn, Anti-Realist Expressivism and Quasi-Realism, in OXFORD HandBook of ETHICAL Theory (David Copp ed. 2009); Joyce, supra note 46; Richard Joyce, Projectivism and Quasi-Realism, StAn. ENCYCLOPEDIA PHIL. (2015), https://plato.stanford edu/entries/moral-anti-realism/projectivismquasi-realism.html; von Roojen, supra note 46.

86. See URMSON, supra note 46; Satris, supra note 46.

87. See, e.g., Carla Bagnoli, Constructivism in Metaethics, STAN. $\begin{array}{llll}\text { ENCYCLOPEDIA PHIL. (June 2017), } & \text { 23, }\end{array}$ https:/plato.stanford.edu/entries/constructivism-metaethics/; David O. Brink, Rawlsian Constructivism in Moral Theory, 17 CAN. J. PHIL. 71 (1987).

88. See, e.g., George Klosko, Political Constructivism in Rawl's Political Liberalism, 91 AM. POL. SCI. REV. 635 (1997).

89. See, e.g., Richard Rorty, Objectivity, Relativism, and Truth: PhIlosophical Papers (1990); Richard Rorty \& Pascal Engel, What's the UsE of Truth? (William McCuaig trans., 2007). See also R. George Wright, Pragmatism and Freedom of Speech, 80 N.D. L. REV. 103 (2004).

90. See, e.g., William Ramsey, Eliminative Materialism, STAN. ENCYCLOPEDIA PHL. (Mar. 2019), https:/plato.stanford.edu/entries/materialism-eliminative/.

91. See, e.g., Daniel Stoljar, Physicalism, Stan. EnCyclopedia PhIL. (Mar. 9, 2015), https://plato.stanford.edu/entries/physicalism/.

92. See, e.g., GuY Axtell, OBjectivity (2016); David O. Brink, Moral Realism AND the Foundations of Ethics (1989); David Enoch, Taking Morality Seriously: A Defense of Robust Realism (reprint ed. 2013); Nicholas Rescher, OBJectivity: The OBligations of IMPERSONAL REASON 
Each of these and other popular schools of thought accept, at best, only a remarkably modest, attenuated role for the idea of truth, or the pursuit thereof. None of these approaches appears to underwrite a judgment that the value of the pursuit of truth justifies any distinctive constitutionally protected status for speech in its recurring conflicts with other, often less metaphysically ambitious values. Again, this is not to endorse or critique any of the above approaches. The point is that none can explain, or otherwise vindicate, a constitutional commitment to speech in particular. ${ }^{93}$

As well, popular notions of an autonomous self cannot justify distinctive constitutional protection for speech. This conclusion flows naturally from minimizing, if not dismissing, any robust ambitious approach to truth or knowledge. Autonomy without a sufficiently robust understanding of truth is already disqualified as a satisfactory reason for endorsing constitutionalized free speech. But the recent tendency to minimize the idea of a meaningful, continuing, autonomous self in particular also deserves brief consideration in its own right. ${ }^{94}$

Consider, for example, Professor C. Edwin Baker's description of the relevant sense of autonomy. ${ }^{95}$ Professor Baker suggests that

[A] person's autonomy might reasonably be

(1997); Russ Shafer-Landau, Moral Realism: A Defense (2005); Geof SayreMcCord, Moral Realism, Stan. Encyclopedia Phil. (Feb. 3, 2015), https://plato.stanford.edu/entries/moral-realism/. See also DOES ANYTHING ReALly Matter?: Essays On PARFit On OBJectivity (1st ed. 2017); Tim Maudlin, The Defeat of Reason, Bos. REV. (June 1, 2018), www.bostonreview.net/science-nature-philosophy-religion/tim-maudlindefeat-reason.

93. Professor Steven D. Smith critiques the short-sightedness of attempts to ground a convincing, effective, motivating approach to valuing freedom of speech on skeptical or relativist grounds. Professor Smith also doubts the suitability of skeptical or minimalist approaches to any autonomous self in validating autonomy and self-realization as core free speech values. See Steven D. Smith, Skepticism, Tolerance, and Truth in the Theory of Free Expression, 60 S. CAL. L. REV. 649, 653, 677-78 (1987).

94. We assume that a democratic self-governance justification for free speech will likely depend on a sufficiently meaningful understanding of truth and of autonomy, and will thus rise or fall with those lines of justifying free speech.

95. See C. Edwin Baker, Autonomy and Free Speech, 27 Const. Comment. 251,253 (2011). 
conceived as her capacity to pursue successfully the life she endorses-self-authored at least in the sense that no matter how her image of a meaningful life originates, she can endorse that life for reasons she now accepts. ${ }^{96}$

This is a mainstream understanding of what autonomy, in the relevant sense, amounts to. ${ }^{97}$ But on standard interpretations, it can hardly underwrite distinctive constitutional protection for speech.

Classically, one might well have asked also about the nature of the process by which the person in question initially arrived at, now endorses, and currently approves of her own continuing endorsement of her successfully pursued life goals. Professor Baker sets aside questions as to how the person's life goals were initially generated. ${ }^{98}$ His focus is instead on the person's mere current endorsement of the person's beliefs, ${ }^{99}$ however acquired, and of the person's motivating reasons. ${ }^{100}$ The problem is that just as one's initial inclinations to pursue one goal or another may have been mechanically, or coercively, caused, so certainly may be one's current endorsement of those inclinations. ${ }^{101}$ Such

96. Id.

97. See, e.g., Sarah Conly, Against Autonomy: Justifying Coercive Paternalism (2013); Gerald Dworkin, The Theory and Practice of Autonomy (1988); Jason Hanna, In Our Best Interest: A Defense of PATERNAlism (2018); ANDREW SNEDDON, AutONOMY (2013); THE InNER Citadel: Essays On Individual Autonomy (Christine Schultz ed., 2014) (1989); Marina Oshana, How Much Should We Value Autonomy?, in AUTONOMY 99 (Ellen Frankel Paul et al. eds., 2003); R.S. Downie \& Elizabeth Telfer, Autonomy, 46 J. Royal Inst. PhIL. 293 (1971); Robert Young, Autonomy and the "Inner Self", 17 AM. PHIL. Q. 35 (1980).

98. See Baker, supra note 95, at 253.

99. See id.

100. See id.

101. See, e.g., sources cited supra notes 90-91. See also Francis CrICK, The Astonishing Hypothesis: The Scientific Search for the Soul 3 (First Touchstone ed. 1995); Joshua D. Greene, Social Neuroscience and the Soul's Last Stand, in SOCIAL NEURoscience: TOWARD UNDERSTANDING THE UNDERPINNINGS OF THE SOCIAL MIND 263 (Alexander Todorov et al. eds., 2011); Anthony R. Cashmore, The Lucretian Swerve: The Biological Basis of Human Behavior and the Criminal Justice System, 107 PROC. NAT'L ACAD. SCI. 4999 (Mar. 9, 2010); Carol Hoefer, Causal Determinism, STAN. EnCYCloPedia PHIL. (Jan. 21, 2016), https://plato.stanford.edu/entries/determinism-causal/ (discussing the deterministic events, randomness, and sheer luck). See generally ALAN WERTHEIMER, COERCION (2016 ed.) (discussing the implication 
coercion can hardly be generally compatible with meaningful autonomy.

In the alternative, consider a process of belief formation and endorsement that is entirely reducible to the mere interactions of waves and particles, on whatever scale; or, more concretely, one might think of controlling the person's "endorsement" via, say, non-consensual brain implants, hostile socialization, surreptitious drugging, behavioral conditioning, or any other form of coercive influence, all of which would be incompatible with standard views of meaningful autonomy. ${ }^{102}$ Even if one wished to think of autonomy as somehow compatible with typical forms of coercion, attempting to bring coercion in general into play at the very foundation of constitutional freedom of speech simply does not seem plausible.

Professor Baker's account does, however, specify that the subject's endorsement has been based on acceptable reasons. ${ }^{103}$ The problem here is that the very idea of a human's actions being genuinely motivated, or effectively caused, by anything as abstract and ethereal as a reason is of currently diminished appeal. ${ }^{104}$ If, as we have increasingly come to believe, everything is or can be reduced to the realm of the physical, ${ }^{105}$ the place for causally effective reasons, as normally understood, becomes dubious. Whatever the idea of "a person's control over her own reasoning processes" 106 is intended to mean, any such control is increasingly thought to be either impossible, or else not so distinctive as to validate a constitutional right to freedom of speech. ${ }^{107}$

of coercion for autonomy); NOMOS XIV: COERCION (J. Roland Pennock \& Alan W. Chapman eds., 1972); Scott Anderson, Coercion, STAn. EnCyClopedia PhIL. (Oct. 27, 2011), https://plato.stanford edu/entries/coercion/.

102. See, e.g., WERTHEIMER, supra note 101; NOMOS XIV: COERCION, supra note 101; Anderson, supra note 101.

103. See Baker, supra note 95.

104. See, e.g., Contemporary Materialism: A Reader (Paul K. Moser \& J.D. Trout eds., 1995); J. J. C. Smart, Materialism, 60 J. PHIL. 651 (1963).

105. See Baker, supra note 95.

106. David A. Strauss, Persuasion, Autonomy, and Freedom of Expression, 91 Colum. L. REV. 334, 354 (1991) (discussing an extended series of causal events, encompassing merely randomly probabilistic events, that happens to involve or terminate in brain processes does not seem to generate a normatively decisive distinction between autonomy and non-autonomy).

107. Part of the problem is that we tend increasingly to reject the essential metaphysics of classical Kantian autonomy, while attempting to 
This particular free speech value is often stated, however, not in terms of autonomy, but in terms of something like selfrealization, self-fulfillment, self-development, self-perfection, or self-actualization. ${ }^{108}$ These conceptions do not bypass the fundamental problem of a diminishing cultural belief in the sort of metaphysical freedom ultimately required for a sufficient justification for constitutional freedom of speech. Briefly put, if we are somehow reducible to anything like atoms and the void, ${ }^{109}$ sacrificing less ambitious values, such as sensory pleasure, for the sake of an illusory sense of metaphysical freedom will ultimately have minimal appeal.

But even if the problems that any combination of inevitable causal chains and sheer randomness pose for sufficiently meaningful freedom can be set aside, there remains the fact that both autonomy and self-realization (and a variety of synonyms) have undergone a process of cultural flattening akin to what we have recognized in ethical thinking more generally. ${ }^{110}$ Autonomy and self-realization can certainly be taken in thin, minimalist senses ${ }^{111}$ requiring little in the way of metaphysics. ${ }^{112}$ The problem, though, is that to the extent that

retain its persuasive force and appeal. See Susan J. Brison, The Autonomy Defense of Free Speech, 108 ETHICS 312, 323 (1998). Kantian autonomy classically requires robust notions of reason, dignity, and freedom of the will independent of any physical or biological causes. See, e.g., IMMANUEL Kant, Groundwork of THE METaphysics of Morals 114-16 (H.J. Paton trans., Harper ed. 1964). See also Thomas E. Hill JR., AUTONOMY and SELF-REsPect 29 (1991); Christine M. Korsgaard, Creating the Kingdom of Ends 25 (1996).

108. See sources cited supra note 67.

109. See Baker, supra note 95. Another historically popular view, compatibilism, has long attempted to square universal causal determinism and randomness with some sort of meaningful freedom of the will. See, e.g., Michael McKenna, Compatibilism, Stan. Encyclopedia Phil. (Feb. 25, 2015), https:/plato.stanford.edu/entries/compatibilism/. See John Perry, Wretched Subterfuge: A Defense of the Compatibilism of Freedom and Natural Causation, 84 Proc. \& Addresses Am. PhIL. Ass'n 93 (2010) (borrowing his title from Immanuel Kant's less favorable assessment of the compatibilist project), for an attempt at reconciling causal forces with sufficiently meaningful freedom of the will.

110. See sources cited supra notes 82-94.

111. See sources cited supra notes 92-98.

112. By contrast, consider the robust metaphysical objectivism of Plato and Aristotle's understanding of the development of human potential to a genuinely higher and better, and not merely preferred, state. See, e.g., Christopher V. Mirus, The Metaphysical Roots of Aristotle's Teleology, 57 REV. MeTAPHysics 699 (2004); John M. Rist, Some Aspects of Aristotelian Teleology, 
we now tend to reduce self-realization to some forms of personal preferences, perhaps endorsed across time, ${ }^{113}$ the idea of selfrealization either frequently conflicts with the constitutional status of free speech ${ }^{114}$ or is insufficient to justify the costs that freedom of speech must inevitably impose in terms of other values. ${ }^{115}$ Freedom of speech may promote the fulfillment, for example, of some sustained preferences. But why presume that those preferences are themselves really preferable to any equally steady or intensely endorsed preferences with which freedom of speech conflicts? Sustained, intense, and widespread preferences are likely to appear on both sides of a free speech case. And typically enough, free speech cases pit majority regulatory preferences against numerical minority speaker preferences.

IV. The Worth of Freedom of Speech as Dependent Upon Its Broader Cultural Context

It may be possible to think of constitutional freedom of speech as a good thing, including its basic free speech values, apart from its consequences. ${ }^{116}$ Perhaps one could say that living under freedom of speech confers a kind of dignity on everyone, regardless of any effects thereof on the pursuit of truth, democracy, or self-realization. But it is difficult to see any such universal bestowal of meaningful dignity as independent of the contemporary culture. Depending upon the current state of cultural development, any such effect of free speech on dignity

96 Transactions \& Proc. Am. Philological Ass'n 337 (1965).

113. See, e.g., sources cited supra notes 97-98.

114. See, e.g., Richard Delgado, Words That Wound: A Tort Action for Racial Insults, Epithets, and Name-Calling, 17 HARV. C.R.-C.L. L. REV. 133 (1982); Charles R. Lawrence, If He Hollers Let Him Go: Regulating Racist Speech On Campus, 1990 DukE L. J. 431 (1990); Mari Matsuda, Public Response to Racist Speech: Considering the Victim's Story, 87 MICH. L. REV. 2320 (1989).

115. See R. George Wright, Dignity and Conflicts of Constitutional Values: The Case of Free Speech and Equal Protection, 43 SAN DIEGO L. REv. 527 (2006), for discussion in one important context. Of course, values such as equality or dignity may ultimately require a metaphysically ambitious defense as well. But the costs of free speech may also be felt in terms of sheer pain and suffering not requiring any controversial metaphysical assumptions, for example.

116. See generally Greenawalt, supra note 63. 
may be either enhanced or minimized. It may, by analogy, be dignity-enhancing to have access to a comprehensive library, but less so, or even dignity-impairing, if we have been made only minimally capable of any meaningful use of that library. ${ }^{117}$

In any event, it is clear that the worth of constitutional free speech in promoting the pursuit of truth, effective democratic processes, and meaningful self-realization depends upon the plainly variable character of the underlying culture. A culture that places reduced emphasis on the pursuit of actual knowledge and truth, or on informed political dialogue and debate on the merits of issues, or on one's own genuine personal deficiencies, excesses, and attempts at self-realization or perfection, is unlikely to benefit optimally from freedom of speech.

It would not be difficult for an outside observer to conclude that our broader culture has relevantly improved over time in some respects, while measurably regressing in others. We now have widely, if not entirely freely, available databases affording instantaneous access to detailed elements of most world cultures. ${ }^{118}$ But there can be no immediate inference from internet and social media use to greater relevant knowledge, enhanced democratic functioning, or to enhanced autonomy and meaningful self-realization.

Thus, even if internet use, social media time, e-books, and magazines are factored in, there is clear evidence of cultural trends non-conducive to realizing, or even concern for, the three basic free speech values. The point is partly that key sociocultural indicators are not high enough, but also that those indicators have generally been trending down over the past several generations. In these respects, the cultural soil in which the constitutional institution of free speech is planted has become less effective in producing the classically anticipated

117. Or, more narrowly, consider a potentially dignity-conferring single book, written in a language we chose never to learn.

118. Google processes more than 60 thousand search queries per second, or 2 trillion such queries per year. Danny Sullivan, Google Now Hondles at Least 2 Trillion Searches Per Year, SEARCH EngINE LAND, (May 24, 2016, 12:00 PM), https:/searchengineland.com/google-now-handles-2-999-trillionsearches-per-year-250247. We here set aside any possible issues of conscious or unconscious bias of any content provider, in any respect, that might impair realizing the three basic free speech values, given the difficulty of comparing media biases before and after the internet and social media technology revolutions. 
benefits of freedom of speech.

First, consider the phenomenon of meaningful literacy. Whether reading via screens is equally valuable as the reading of classic texts or not, ${ }^{119}$ there is evidence that reading of the sort that infuses distinctive value and meaning into free speech protection has been declining in our culture over time. ${ }^{120}$ It is suggested instead that "the long march to secondary orality seems well underway." 121 Thus, the reported gradual decline of reading scores, ${ }^{122}$ and perhaps not coincidentally, in relevant vocabulary, has occurred. ${ }^{123}$ Recent measures of basic competence as well in crucial subjects including history and

119. See, e.g., NiChOlas CarR, The SHallows: What the InTERNET IS DOING TO OUR BRAINs (2010) (discussing doubts about the value of reading via screens); Gian Paolo Barbetta et al., Let's Tweet Again? The Impact of Social Networks on Literature Achievement in High School Students: Evidence from a Randomized Controlled Trial, 81 WoRKING PAPER SERIES 2 (May 2019), https://dipartimenti.unicatt.it/economia-finanza-def081.pdf; Nicholas Carr, Is Google Making Us Stupid?, THE ATLANTIC, (July/Aug. 2008), www.theatlantic.com/magazine/archive/2008/07/is-google-making-us-

stupid/306868 (discussing effects on the ability to concentrate for sustained periods).

120. See Steven Johnson, The Fall, and Rise, of Reading, 65 CHRON. HighER EDUC. 14-15 (Apr. 26, 2019) (documenting not just low levels of high school, college, and graduate-level educated student reading, but significant decreases over recent decades, including a $13 \%$ decrease in prose literacy among the graduate school-level students surveyed).

121. Caleb Crain, Why We Don't Read, Revisited, NEw YoRkER (June 14, 2018), https:/www.newyorker.com/culture/cultural-comment/why-we-dontread-revisited.

122. See, e.g., Erica L. Meltzer, The Death of the Lecture and the Decline of Reading Scores, CRITICAL READER (June 30, 2018), https:/thecriticalreader.com/the-death-of-the-lecture-and-the-decline-ofreading-scores/.

123. See, e.g., E. D. Hirsch Jr., Vocabulary Declines, with Unspeakable Results, WALL ST. J. (Dec. https://www.wsj.com/articles/SB10000872396390444165804578010394278688 454. See also E. D. Hirsch, Jr., Reading Comprehension Requires KnowledgeOf Words and the World: Scientific Insights Into the Fourth-Grade Slump and the Nation's Stagnant Comprehension Scores, 27 AM. EDUCATOR 10, 21 (2003) (discussing the degree of literacy as dependent upon vocabulary and, fundamentally, upon knowledge of the world). On a number of measures, though, it appears that reading scores have been flat, rather than gradually declining, over recent decades. See, e.g., Natalie Wexler, Why American Students Haven't Gotten Better at Reading in 20 Years, THE ATLANTIC (Apr. 13, 2018), www.theatlantic.com/education/archive/2018/04/american-studentsreading $/ 557915$. 
elementary civics, ${ }^{124}$ elementary science methods and results, ${ }^{125}$ practical arithmetic and mathematics, ${ }^{126}$ basic positive

124. See, e.g., Americans Are Poorly Informed About Basic Constitutional Provisions, ANNENBERG PUB. POL'Y CTR. (Sept. 12, 2017), https://www.annenbergpublicpolicycenter.org/americans-are-poorly-informedabout-basic-constitutional-provisions/ (stating that $26 \%$ can name the three federal government branches, as opposed to $38 \%$ as recently as 2011); Allan C. Brownfield, The Danger Ignorance of History Poses to the Future of a Free Society, Am. Council Tr. Alumni (Apr. 22, 2018), https://www.goacta.org/news/the-danger-ignorance-of-history-poses-to-thefuture-of-a-free-society (stating $26 \%$ of surveyed millennials as unable to identify Auschwitz); Edward Luce, U.S. Declining Interest in History Presents Risk to Democracy, FIN. TIMES (May 2, 2019), https://www.ft.com/content/e19d957c-6ca3-11e9-80c7-60ee53e6681d; WW Finds Most Americans Can't Pass Citizenship Test, WoOdROW WILSON NAT'L FELLOWSHIP FOUND. (Feb. https://woodrow.org/news/perspectives/ww-finds-most-americans-cant-passcitizenship-test; Failing Our Students, Failing America (2007), www.americancivicliteracy.org/2007/summary_summary.html. Again, reports of gradual decline may be difficult to disentangle from reports of stagnation at apparently low levels.

125. See, e.g., Clifford N. Lazarus, The Dangers of Scientific Illiteracy, PSYCHOLOGY TODAY (Apr. 20 2007), https:/www.psychologytoday.com/us/blog/think-well/201704/the-dangersscientific-illiteracy (noting the frequency of scientific illiteracy even among politicians and other elites); 'Science Ignorance Is Pervasive in Our Society': Poll Finds Majority of Americans Question Big Bang Theory, CBS DC (Apr. 22. 2014, 8:17 AM), https://washington.cbslocal.com/2014/04/22/science-ignoranceis-pervasive-in-our-society-poll-finds-majority-of-americans-question-bigbang-theory/; Survey Reveals Public Ignorance of Science, NEW ScIENTIST (July 15 , 1989), www.newscientist.com/article/mg12316731-200-survey-revealspublic-ignorance-of-science (surveying 2,000 Americans as well as 2,000 Britons and finding that "[f]orty-three percent of Americans know that electrons are smaller than atoms" and almost half of Americans surveyed "know that it takes the Earth a year to orbit the Sun"). It should be emphasized that the problem of public and elite-level scientific ignorance, especially across a broad range of issues, is not confined to any particular segment of the political spectrum. See, e.g., Ilya Somin, Public Ignorance and GMO Foods, VOLOKH CONSPIRACY (Dec. 28, 2017, 3:16 PM), https://reason.com/2017/12/28/public-ignorance-and-GMO-foods. See also Katharine Mangu-Ward, 80 Percent of Americans Want to Label Food That Contains DNA, REASON (May 24, 2016, 3:25 PM), https://reason.com/2016/05/24/80-percent-of-americans-want-to-label-fo/.

126. See, e.g., John Allen Paulos, Innumeracy: Mathematical IlliteraCY AND ITS CONSEQUENCES (First Paperback ed. 2001) (1988) (discussing otherwise well-educated citizens). Anecdotally, one notes the marketplace failure of the A\&W Third Pounder Burger, priced the same as and otherwise equaling the classic Quarter Pounder, precisely because more than half of those surveyed believed that a third of a pound is less than a quarter of a pound, given that three is indeed less than four. This is presumably a question in which the respondents were directly invested, as distinct from some 
economics, ${ }^{127}$ and world religions ${ }^{128}$ have been less than encouraging.

This is not to suggest that a modestly educated public cannot benefit from constitutionalizing freedom of speech. Free speech may well tend in some respects to facilitate, for example, the collective search for truth, even if most of the public happens to be deficiently educated. But as underlying educational levels ${ }^{129}$ slowly decline or stagnate disappointingly, the risks and costs of prioritizing speech rights over other significant interests inevitably tend to increase. ${ }^{130}$

This is not to deny that much basic ignorance, especially in a high wealth society with an intensive division of labor, is entirely rational from the standpoint of any given individual. ${ }^{131}$ Most simply, if one's own vote, however well-informed, is unlikely to tip a given election, one's rational course in

remote, abstract public policy issue. See Stacy Conradt, Why No One Wanted A\&W'S Third-Pound Burger, Mental Floss (Feb. 26, 2016), http://mentalfloss.com/article/76144/why-no-one-wanted-aws-third-poundburger.

127. See, e.g., Bryan Caplan, Straight Talk about Economic Illiteracy, MERCATUS CTR., GEORGE MASON U. (July 2004), https://www.mercatus.org/system/files/Straight-Talk-about-Economic-

Illiteracy.pdf (noting the intuitiveness of economically illiterate beliefs, and the anti-intuitiveness of even some of the most basic positive economic insights). For an interesting response to Caplan's discussion, see Jeffrey Friedman, Irrationality, or Just Plain Ignorance?, CATO UnBound (Nov. 14, 2006), https://www.cato-unbound.org/2006/11/14/jeffrey-friedman/irrationality-orjust-plain-ignorance. Consider also that in a self-indulgent and high wealth culture, it is often simply more gratifying to think of economics in normative terms than in positive or cumulative evidentiary terms. A focus on the normative may relieve any pressures toward numeracy.

128. See, e.g., Stephen Prothero, Religious Literacy: What Every AMERICAN NEEDS to KNOW-AND DOESN'T (EPub ed. 2007); U.S. Religious Knowledge Survey, PEW RES. CTR. (Sept. 28, 2010), www.pewforum.org/2010/09/28/u-s-religious-knowledge-survey.

129. See generally RiCHARD ARUM \& JOSIPA RokSA, ACADEMICALLY ADRIFT: Limited Learning ON College Campuses (2011); Philip Babcock \& Mindy Marks, Leisure College, USA: The Decline in Student Study Time, AM. ENTERPRISE INST. (Aug. 5, 2010), https:/www.aei.org/researchproducts/report/leisure-college-usa/ (discussing the exceptionally broad and significant decreases among all groups in college study time as consistently developing over the past multiple decades).

130. See Patricia RoBerts-Miller, Demagoguery AND DEMOCRACY (2017).

131. See, e.g., Ilya Somin, Democracy and Political Ignorance: Why SMALLER GOVERNMENT IS SMARTER (2d ed. 2016) (discussing rational voter ignorance of politics and economies). 
nonetheless voting may well be merely to think well of oneself, or to attempt to ingratiate oneself with some group with which one identifies, or from which one seeks approval. Even if one does not publicize how one voted or intends to vote, the personal payoff from thereby associating oneself with a preferred group may outweigh the costs of voting, let alone the costs of voting on the basis of any reasonable assessment of one's own biases and limitations. ${ }^{132}$

Finally, the importance of levels of the public's competence in general does not lessen the distinctive importance of competency levels among cultural elites. It is subject to doubt whether our contemporary elites tend to display the intellect, interactive style, priorities, and the character and public virtues necessary to meaningfully promote the broader cultural practices of truth seeking, democratic dialogue, and genuine self-fulfillment via free speech. ${ }^{133}$ One dimension of this problem may be the degree to which both elites and non-elites tend to

132. See Daniel Kahneman, Thinking, FAST AND Slow (2011). See also EPIC-SUMmary, SUMmarY: THINKING, FAST AND SlOW (2019) (summarizing Daniel Kahneman's book). Alternatively, one could think of one's chosen political antagonists as less nuanced and less cognitively complex than one's chosen allies. See Lucian Gideon Conway III et al., Are Conservatives Really More Simple-Minded than Liberals? The Domain Specificity of Complex Thinking, 37 POL. PsYCHOL. 1 (2015); John T. Jost, Ideological Asymmetries and the Essence of Political Psychology, 38 POL. PSYCHOL. 167 (2017); Joris Lammers et al., The Political Domain Appears Simpler to the Politically Extreme Than to Political Moderates, 8 SOC. Psychol. \& PERSONALITY SCI. 612 (2017). Nor is politics a realm in which one's mistaken judgments are likely to be fully recognized in their frequency and full weight. See DAVID DUNNING, Self-Insight: Roadblocks and Detours On the Path to Knowing Thyself (2012); Philip E. Tetlock, Expert Political JudgMent: How GoOd Is It? How CAN WE KNOW? (2005).

133. See, e.g., Chris Hayes, Twilight of the Elites: America After Meritocracy (2012); Tom Nichols, The Death of Expertise: The Campaign Against Established Knowledge and Why It Matters (2017); Tetlock, supra note 132; Conor Friedersdorf, How Stigma Sows the Seeds of Its Own Defeat, THE ATLANTIC (Dec. 2016), https:/www.theatlantic.com/politics/archive/2016/12/how-stigma-sows-seedsof-its-own-defeat/509273/ (observing that "only 19 percent of millennials agree that it would be illegitimate for the military to take control of the government," and in general, that "[i]n the Western world, the percentage of people who say that is essential to live in a democracy is in precipitous decline"); Lawrence R. Jacobs, The Cluelessness of the Elites, STAR TRIB. (Mar. 9, 2019), http://www.startribune.com/the-cluelessness-of-the-elites/506905552/. These sources variously emphasize perceived inadequacies of contemporary elites, the inadequacies of non-elites in failing to appropriately respect elite expertise, or some pathology flowing from elite/non-elite interaction. 
avoid any meaningful reassessment of their views and judgments in the face of apparently important, and particularly adverse, new information. ${ }^{134}$ The classic study of largely unrevised basic beliefs in the face of apparent disconfirmation, When Prophecy Fails, ${ }^{135}$ focused on a fringe UFO cult's predictions of the end of the world. ${ }^{136}$ Today's version of this phenomenon of remarkably refractory persistence of belief in the face of counter evidence is much broader. We cling to beliefs despite increasingly prominent counter-evidence. ${ }^{137} \mathrm{~A}$ reasonable sense of fallibility is often replaced by what amounts to a remarkable imperviousness to evidence.

Under these contemporary circumstances, the realistic value of traditional free speech doctrines is gradually diminished.

\section{Some Competing Value Costs of Free Speech Under Contemporary Cultural Conditions}

One important dimension of our free speech problem is that evolving cultural conditions have reduced the usefulness of free speech in promoting the search for truth, meaningful democracy, and autonomy or self-realization in any meaningful sense. ${ }^{138}$ This amounts to the reduced value side of the problem. Some attention should be paid as well to the increasing cultural cost $\mathrm{t}^{139}$

134. See TETLOCK, supra note 132.

135. See Leon Festinger, HenRy Riecken, \& Stanley Schachter, When PropheCY FAILS (Reprint ed. 2009) (1956).

136. See id.

137. One common reaction, beyond denial or some other classical defense mechanism, seems to involve not publicly resurrecting the apparently discredited belief until some time has passed, or until the context has somehow changed. See FREUD, supra note 8. Apparently, refuted beliefs often go into a sort of dormant or latent phase.

138. See infra Parts III, IV. It is also possible that the current costs of restrictions on speech are mitigated by an increasing variety of protective techniques in communicating, collectively referred to as esoteric writing. See Arthur M. Melzer, Philosophy Between the lines: The Lost History of Esoteric Writing (2014); Paul J. Bagley, On the Practice of Esotericism, $53 \mathrm{~J}$. Hist. IdEAS 231 (1992).

139. The term "cultural cost" is used here to distinguish social costs of the content or message of speech, or of the sheer inescapability of speech in public or private spaces, from reduced costs of speech in terms of, say, increased low-cost access via social media to a potentially broad audience for one's messages. See sources cited supra notes $67,122$. 
dimension of the free speech problem. It is easier, however, to classify the purported benefits of free speech ${ }^{140}$ than it is to similarly categorize its cultural costs. ${ }^{141}$

Thus, no useful inventory of all of the increasing cultural costs of freedom of speech is realistically possible. We can, however, take samplings of some of the social costs of free speech in selected contexts. Below, we briefly consider, in turn, the increased cultural significance of college campus hate speech ${ }^{142}$; of group-disparaging speech by lower-level public school students ${ }^{143}$; and of the group-disparagement potential of registered trademarks. ${ }^{144}$

As a matter of sheer numbers, the cultural costs of university campus hate speech, whether legally protected or not, must necessarily have increased over the past several decades. This is largely a matter of simple arithmetic. After all, the visible presence of many of the now typical hate speech victims was modest in the decades of the 1950's and 1960's. ${ }^{145}$ In particular, "[p]rior to the late 1960[']s most of the nation's highest-ranked colleges and universities enrolled token numbers of black students. In some cases, there were no African-American students on the campuses of our most highly regarded institutions." 146 More broadly, from 1976 to 2008, Hispanic college enrollment rose six-fold, ${ }^{147}$ while black student enrollment rose from 943,000 to $2,269,000 .{ }^{148}$ The percentages II.

140. Under our conventional free speech value headings. See infra Part

141. To a degree, however, some of the cultural costs of free speech could be formulated in terms of losses of autonomy or of self-realization. See sources cited supra note 114 (discussing some effects of hate speech).

142. See infra notes 151-160 and accompanying text.

143. See infro notes 161-172 and accompanying text

144. See infra notes 173-181 and accompanying text. These cultural costs turn on the message of speech in question. Some of the increasing cultural costs of free speech, however, may reflect the sheer inescapability of speech in public places, rather than the content of any speech. See R. George Wright, Public Fora and the Problem of Too Much Speech, 106 KY. L. J. 409 (2016).

145. See JBHE Foundation, Inc., Long-Term Black Student Enrollment Trends at the Nation's Highest-Ranked Colleges and Universities, 8 J. BLACKS Higher Educ. 10, 10 (1996); Susan Aud et al., Status and Trends in the Education of Racial and Ethnic Groups, U.S. DEP'T OF EDUC., NAT'L CTR. EDUC. STAT. (July 2010).

146. JBHE Foundation, Inc., supra note 145, at 12.

147. Susan Aud et al., supra note 145, at 122.

148. Id. 
of women college students also increased over the same period. ${ }^{149}$

Doubtless, the basic free speech values have been, in some respects, variously furthered by these very trends. But our focus here on the cultural costs of free speech constitutionalization ${ }^{150}$ requires that we take account also of the costs of identity-based assaultive speech on campus. Consider, concretely, university campus-based incidents of the sort more generally described by Professor Richard Delgado:

$[F]$ ace-to-face vituperation can pollute the environment in ways almost as damaging as billboards and monuments. A minority group member who is the target of a racial name hurled out of the blue is apt to review it in his mind many times. He or she may recount it to friends and family, who may, in turn, tell others . . . . ${ }^{151}$

These sorts of harms may be largely intangible, but they adversely implicate the free speech value of self-realization of the target or victim, in multiple ways. ${ }^{152}$ Nor are the harms of personal insults and epithets typically reducible through what classical free speech theory refers to as "more speech," or counterspeech. ${ }^{153}$ Indeed, we might well conclude that in typical cases, attempting to rebut intentionally degrading and scurrilous speech on the merits, as though in some sort of good faith mutual inquiry into the truth, would itself be objectively humiliating. ${ }^{154}$

149. Id.

150. We here set aside distinctions between federal and state constitutional free speech law, federal statutory and regulatory protection of free speech, and the state action requirement for violation of the First Amendment. See R. George Wright, Campus Speech and the Functions of the University, 43 J. C. \& U. L. 1 (2017), for further discussion.

151. Richard Delgado, Book Review, 47 L. \& SOC'Y REV. 232, 233 (2012) (reviewing Jeremy Waldron, Dignity and Defamation: The Visibility of Hate, 123 HARV. L. REV. 1596 (2010)).

152. See sources cited supra note 114.

153. See sources cited supra notes 20-23. Note that these types of harms of campus hate speech are not spread evenly across members of dominant and traditionally subordinated groups.

154. This may be true even if one assumes that the presumed audience for such a rebuttal is still available. See, e.g., ERWIN CHEMERINSKY \& HowARD 
Some similar costs of contemporary free speech law arise in public school student speech cases, with the addition of distinctive costs to the multiple socializing functions of the public schools. 155 The eventually mooted case of Harper $v$. Poway Unified School District considered whether a public high school may "prohibit students from wearing t-shirts with messages that condemn and denigrate other students based on their sexual orientation[.]"156 The court recognized that public schools have a number of commonly recognized purposes, any one of which could potentially conflict with broadly protected student speech rights. ${ }^{157}$

In particular, the court recognized the possibility of persistent psychological injury stemming from even nonconfrontational condemnation "on the basis of a core identifying characteristic such as race, religion, or sexual orientation ...."158 One might well think of such injuries not only in terms of privacy, ${ }^{159}$ security, ${ }^{160}$ and equal educational opportunity, ${ }^{161}$ but as well, ironically, in terms of the basic free speech value of individual autonomy and self-realization, ${ }^{162}$ to the extent to which we still wish to take the ideas of autonomy and self-realization seriously. In general, the costs of recognizing "freedom for the thought that we hate" 163 are not equivalent to freedom for the thought that foreseeably wounds or impairs at a fundamental personal and emotional level. ${ }^{164}$

Gillman, Free Speech On Campus (2017); Nadine Strossen, Hate: Why We Should Resist It with Free SPEech, Not Censorship (2018); KeIth E. Whittington, Speak Freely: Why Universities Must Defend Free Speech (2018); Andrew Altman, Liberalism and Campus Hate Speech: A Philosophical Examination, 103 ETHICS 302 (1993).

155. See, e.g., Harper v. Poway Unified Sch. Dist., 445 F.3d 1166 (9th Cir. 2006), vacated as moot, 549 U.S. 1262 (2007); R. George Wright, Post-Tinker, 10 STAN. J. C.R. \& C.L. 1 (2014) (noting the variable and multidimensional role of the public schools in basic education, teaching tolerance, equality, and mutual respect in political matters).

156. See Harper v. Poway Unified Sch. Dist., 445 F.3d 1166, 1170 (9th Cir. 2006), vacated as moot, 549 U.S. 1262 (2007).

157. See id at 1176.

158. Id. at 1178 .

159. See id.

160. See id.

161. See id.

162. See generally sources cited supra notes 93-116

163. United States v. Schwimmer, 279 U.S. 644, 655 (1929).

164. See Harper, 445 F.3d at 1178-79. The effects of an abstractly 
Consider, as well, the cultural costs of registering trademarks that disparage particular groups through recognizable slurs and epithets. ${ }^{165}$ Part of the problem in fully recognizing the cultural costs of officially registering such trademarks may lie in the earnest desire of some trademark applicants to re-appropriate, or to drain the pejorative associations of, the typically disparaging slur or epithet in question. ${ }^{166}$ However laudable, or effective, such intentions may conceivably be, they do not present the same problems of cultural cost as unequivocally disparaging trademarks.

It is possible that market forces, if not simple decency, will tend to suppress the desire to register a group-disparaging trademark, or at least to reduce the value of such a mark. ${ }^{167}$ Our concern, however, is with trends in the cultural costs of groupdisparaging marks. Of late, even national-level sellers of goods and services have tended to reject the traditional strategy ${ }^{168}$ of seeking to broaden their market by avoiding political offense. ${ }^{169}$

expressed ideological statement, and of direct disparagement based on core personal identity, thus need not be the same.

165. See Matal v. Tam, 137 S. Ct. 1744, 1751 (2017) (quoting 15 U.S.C. $\S 1052$ (a) to address trademarks that may "disparage ... or bring ... into contempt, or disrepute" any person). See also Wandering Dago, Inc. v. Destito, 879 F.3d 20, 24 (2d Cir. 2018) (citing id.); In re Brunetti, 877 F.3d 1330, 1336 (Fed. Cir. 2017) (citing 15 U.S.C. $\$ 1052$ (a) in the context of a different trademark provision addressing "immoral" or "scandalous" matter), aff'd sub nom. Iancu v. Brunetti, 139 S. Ct. 782 (2019). See generally Lisa P. Ramsey, Free Speech Challenges to Trademark Law After Matal v. Tam, 56 Hous. L. REV. 401 (2018). 20 .

166. See generally Matal, 137 S. Ct 1744; Wandering Dago, Inc., 879 F.3d

167. See generally R. George Wright, Political Discrimination by Private Employers, 87 U. CiN. L. REV. 761 (2018).

168. As legendarily articulated by Michael Jordan, to the effect that Republicans buy sneakers too. But see Giri Nathan, Did Michael Jordan Ever Say "Republicans Buy Sneakers, Too"?, DEADSPIN (Jul. 26, 2016, 2:02 PM) https://deadspin.com/did-michael-jordan-ever-say-republicans-buy-sneakers1784530317.

169. See, e.g., Martin Armstrong, America's Most Polarizing Brands, StATISTA (Oct. 25, 2017), www.statista.com/chart/11601/america's-mostpolarizing; How Americans View the Politics of Brands, AxIos (Mar. 1, 2019), https://www.axios.com/political-polarization-business-politics-brandsf7b78ed9-693f-4106-8895-4c8409859f8b.html; Oliver McAteer, How Brands Can Benefit From Polarization, CAMPAIGN US (Sept. 21, 2018), www.campaignlive.com/article/brands-benefit-polarization/1493443; Patricia Nakache, Polarization Is an Opportunity For Mission-Driven Brands, FAST Co. (Nov. 7, 2018), www.fastcompany.com/90264170/polarization-is-anopportunity; Nailya Ordabayeva, How Liberals and Conservatives Shop 
Corporations are now often willing to risk, if not invite, the alienation of some potential customers for the sake of a better image with, and greater loyalty from, other sometimes demographically targeted customers. ${ }^{170}$

In light of this trend, consider the case of small business enterprises that believe, perhaps rightly, that in an era of increasingly extreme, encompassing, and intense polarization, ${ }^{171}$ they may benefit by alienating perhaps even $90 \%$ of the broad possible customer base for the sake of greater loyalty from the remaining $10 \%$. Why not then obtain, and publicize, what may seem to some an officially endorsed trademarking of a crudely disparaging epithet?

The protected free speech status of disparaging epithets, even where such disparagement is clearly intended, would seem to follow from the logic of the case of Matal v. Tam. ${ }^{172}$ The harms of such exposure could track those discussed above. ${ }^{173}$ And there would seem to be no technological guarantees against anyone's involuntary exposure to such trademarks, or to news reports of their existence.

These examples of the evidently increasing cultural costs of constitutionally protected speech certainly do not exhaust the field. There are also arguable cultural costs that are admittedly more diffuse and contestable, but also subtler and pervasive. Consider today's constitutional protection of commercial speech. ${ }^{174}$ Whatever the goals of restrictions on commercial marketing speech, ${ }^{175}$ there are always broader, but admittedly controversial, costs of commercial speech. No doubt, rightly or

Differently, HARV. BUS. REV. (June 19, 2018), https:/hbr.org/2018/06/howliberals-and-conservatives-shop-differently?autocomplete=true.

170. See sources cited supra note 169.

171. Consider the recent rise of the word "hathos" to describe the pleasure people might derive from their hatred of particular other people. See, e.g., More On the Origins of Hathos, WORD PREss (Dec. 22, 2008), https:/thehathos.wordpress.com/2008/12/22/more-on-the-origins-of-hathos.

172. See 137 S. Ct. 1744 (2017).

173. See sources cited supra notes $151,154-64$.

174. See Sorrell v. IMS Health, 564 U.S. 552 (2011) (discussing current Supreme Court doctrine on the scope and protection of commercial speech). In Sorrell, the Court applied some form of "heightened" scrutiny to strike down state statutory restrictions on "the sale, disclosure, and use of pharmacy records that reveal the prescribing practices of individual doctors." Id. at 55772.

175. Id. at $557-72$ 
wrongly, a "consumer's concern for the free flow of commercial speech often may be far keener than his concern for urgent political dialogue."176 But some speech-related cultural cost, of whatever magnitude, is involved in, for example, prescription drug marketing speech.

As it turns out, the apparent competing speech of rival prescription drug sellers is also, more broadly, mutually reinforcing speech. Competing advertisements may, jointly, lead many persons to act as though the best solution for their depression, anxiety, loneliness, and other ills lies in the consumption of prescription drugs. In some cases, this commercial approach may indeed be best. But in other cases, repairing damaged lifestyles and relationships would be more effective. The free speech problem is that protected commercial advertising speech systematically prioritizes the former over the latter. ${ }^{177}$ Other speakers are certainly permitted to argue, on the contrary, for the importance for one's health of lifestyles and relationships. But in the marketplace of ideas, they will normally, and increasingly, ${ }^{178}$ be out-budgeted. ${ }^{179}$

Again, one might dismiss or deny the cultural costs of protected commercial speech, but the broader case for the substantial and increasing cultural costs of protected speech in general remains. As the benefits of protected speech in terms of the historically crucial free speech values decline, the cultural costs of free speech have generally tended to increase. Freedom of speech, as normally understood, is itself substantially and increasingly an anachronistic remnant: a holdover from a previous culture, with only a diminished current justifiability.

176. Id. at 566 (quoting the attorney advertising case of Bates v. State Bar, 433 U.S. $350,364(1977))$.

177. See generally R. George Wright, Freedom and Culture: Why We Should Not Buy Commercial Speech, 72 DENV. U. L. REv. 137 (1994) (elaborating on this admittedly controversial argument).

178. For a sense of the remarkable estimated magnitudes, see Lindsey Tanner, US Medical Marketing Reaches $\$ 30$ Billion, Drug Ads Top Surge, ASSOCIATED PRESS (Jan. 8, 2019), https://www.apnews.com/f44a7baa710d458ca50edd66affe1b91.

179. See id. 


\section{Conclusion}

In broad strokes, the traditionally cited free speech values of the pursuit of knowledge and truth, meaningful democratic self-government, and the promotion of genuine autonomy and self-realization have gradually evolved, in our culture, in ways that have reduced their meaningfulness and their power to justify constitutionally protecting speech generally at the expense of significant and more elemental values. Other ongoing cultural trends, including those related to education, have further reduced the ability of freedom of speech generally to promote its historic basic values and purposes. At the same time, some key cultural costs of freedom of speech have been correspondingly increasing.

The case for a continuing elevated constitutional status for free speech in general has thus weakened over time. The constitutional status of freedom of speech thus amounts, at this point, to a cultural holdover. Those who view these developments as largely regrettable must come to terms with the persistence, and apparent stability, of most of the underlying cultural trends. It is technically possible that these cultural trends could be reversed, in some cases, by an increased cultural emphasis on developing the most valuable versions of what we might call the basic epistemic ${ }^{180}$ virtues. ${ }^{181}$ Whether any such

180. The idea of epistemic virtues and epistemic vices reflects the view that there can be more and less effective ways of forming and testing and revising beliefs of all sorts. See generally J. Turri, Virtue Epistemology, STAN. $\begin{array}{llll}\text { ENCYCLOPEDIA PHIL. } & \text { (Nov. } & \text { 2017), }\end{array}$ https:/plato.stanford.edu/entries/epistemology-virtue.

181. The Court's classic free speech cases themselves sometimes suggest a vital role for widely recognized moral and particularly epistemic virtues. See Whitney v. California, 274 U.S. 357, 375 (1927) (Brandeis, J., concurring), (discussing "courage" as the "secret of liberty"), overruled in part by Brandenburg v. Ohio, 395 U.S. 444 (1969); Thornhill v. Alabama, 310 U.S. 88, 95 (1940) (discussing "fearlessness"). For a discussion of Justice Brandeis' concurrence in Whitney, see Vincent Blasi, The First Amendment and the Ideal of Civic Courage: The Brandeis Opinion in Whitney v. California, 29 WM. \& MARY L. REV. 653 (1988).

For classic expositions of the relevant widely accepted basic virtues, see Aristotle, The NiCOMACHEAN ETHICS (J.A.K. Thomson trans., Further revised ed. 2004) ( $\sim 350 \mathrm{BCE}$ ) (discussing the virtues of courage, temperance or reasonable self-restraint, and prudential wisdom); THE BHAGAVAD-GITA, Krishna's Counsel in Time of War, Thirteenth Teaching (Barbara Stoller Miller trans. 1986) (stating "knowledge means humility, sincerity, nonviolence, patience, honesty ... purity, stability, self-restraint"). Among 
increased cultural emphasis on largely uncontroversial virtues is on the horizon is, for our present purposes, hereby entrusted to the judgment of the reader. In the absence of any such developments, however, we will be increasingly likely, for increasingly evident reasons, to see broad constitutional freedom of speech as variously, "trivial, foreign, and unnecessarily costly," 182 as commonly involving something akin to secular "idolatry," 183 or as a legal practice subject to politicized "weaponization." 184

contemporary writers, see ANDRÉ COMTE-SPONvILLE, A SMALL TREATISE ON THE Great Virtues: The Uses of Philosophy in Everyday Life 31-59 (Catherine Temerson trans., 2001) (1996).

For useful contemporary discussions of the crucial epistemic virtues,

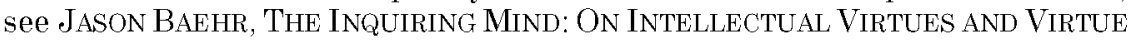
Epistemology (2013); Christopher Peterson \& Martin E. P. Seligman, Character Strengths and Virtues: A Handbook And Classification (2004); Robert C. Roberts \& W. Jay WOOD, InTEllectual VirTuEs: AN EsSAY IN Regulative EPISTEMOLOGY (2009); Heather Battaly, Closed-Mindedness and Dogmatism, 15 EPISTEME 261 (2018); Heather Battaly, Intellectual Perseverance, 14 J. MORAL PHIL. 669 (2017); Paul Bloomfield, Epistemic Temperance, 56 AM. PHIL. Q. 109 (2019); Dennis Whitcomb et al., Intellectual Humility: Owning Our Limitations, XCIV PHIL. \& PHENOMENOLOGICAL Res. 509 (2017); Michael D. Baumtrog, The Willingness to Be Rationally Persuaded, ONTARIO SOC'Y FOR THE STUDY OF ARGUMENTATION (2016), https://scholar.uwindsor.ca/ossaarchive/OSSA11/papersandcommentaries/71/.

For useful background on equality and inequality of persons' relevant epistemic backgrounds in particular decisional contexts, see BRYAN FRANCES, DisAGREement (2014); Bryan Frances \& Jonathan Matheson, Disagreement, STAN. ENCYCLOPEDIA PHIL. (Feb. 23, 2018), https://plato.stanford.edu/entries/disagreement; R. George Wright, Epistemic Peerhood in the Law, 91 ST. JoHN's L. REV. 663 (2017).

Finally, consider that some persons might argue today, whether rightly or wrongly, that a number of the above virtues classically thought to enhance the value of free discussion and debate are not worthy of cultivation by all persons, across the board.

182. For a different context, see Robert F. Nagel, How Useful Is Judicial Review in Free Speech Cases?, 69 CORNELL L. REV. 302, 340 (1984).

183. Steven H. SHIFFrin, What Is Wrong With the First AMENDMENT? $10(2016)$.

184. See Adam Liptak, How Conservatives Weaponized the First Amendment, $\quad$ N.Y. TIMES (June $30, \quad$ www.nytimes.com/2018/06/30/us/politics/first-amendment-conservativessupreme-court.html. 
